\title{
The challenge of gender inequality
}

\author{
Bina Agarwal ${ }^{1,2}$
}

Published online: 15 February 2018

(C) Springer International Publishing AG, part of Springer Nature 2018

Distinguished colleagues and guests, I am greatly honoured to receive this award. I welcome this opportunity to share with you some of the ideas that have occupied me in past decades.

In 1978 a group of poor women farmers in West Bengal, in Eastern India, requested their village council: Please go and ask the government why when it distributes land, we don't get a title? Are we not peasants? If our husbands throw us out, what is our security? These women's questions went to the heart of the genderrelated inequalities that characterised public policy and social science theory in the 1970s-questions which, despite notable progress, still remain centrally relevant.

Conventional economic theory, which strongly influenced public policy, characterised the household as a harmonious unit, driven by altruism and shared purpose. Outlined most explicitly by Nobel Laureate Gary Becker (but implicit in most economic analysis and policy), the unitary household model assumes that all household resources and incomes are pooled; and an altruistic household head, who represents the household's tastes and preferences, ensures equitable allocation of resources and seeks to maximise household utility, subject to a budget constraint.

If these assumptions were valid, we would find no major inequalities within families. All family members would benefit, even if the government transferred assets to male household heads; and the peasant women I quoted above would not

This editorial is a slightly revised transcript of the speech delivered by the author at the 2017 Balzan Prize winners' Interdisciplinary Forum, held in Berne on 16 November 2017. The event was organized by the International Balzan Prize Foundation and the Swiss Academies of Arts and Sciences. The author was awarded the International Balzan Prize 2017 for her work in Gender Studies.

Bina Agarwal

bina.india@gmail.com

1 Global Development Institute, University of Manchester, Manchester, UK

2 Institute of Economic Growth, Delhi, India 
be protesting. Reality is different. In fact, over the years, every assumption of the unitary model has been challenged by empirical evidence, which reveals deep gender inequalities within households in access to assets, education, healthcare, work sharing and, most of all, in our freedom to choose what we have reason to value (a key capability: Sen 2009).

Similarly, beyond the household, core economic and social institutions such as the labour market, the community and the State, reveal deeply embedded inequalities. Labour markets show large gender wage gaps and job segregation by gender; communities enforce social norms which restrict women's mobility and life options; and institutions of governance-be they village councils or legislatures-more often than not, reveal women's absence rather than their presence.

Hence, although today wealth and income inequality have come to the forefront of academic and policy debate, the question of gender inequality still remains largely on the margins-inequality which can have serious adverse effects not only on the welfare of women and children, but also on a country's development. This provides the backdrop to the specifics of my own research.

The most important factor that has propelled my work over the years is a deep interest in understanding the processes that underlie poverty and inequality, especially those predicated on gender, and in finding pathways to alleviate these deprivations and move towards sustainable livelihoods. This led me to focus especially on agriculture and the rural sector in developing countries where most of the world's poor are located, but which also hold great potential for transformation.

Broadly my research falls under three themes (Agarwal 2016):

- Agriculture, technology and food security.

- Property, family and the State.

- Environmental change and collective action.

I approach these subjects through the lens of political economy and gender, with an emphasis on both theory and empirical analysis. Theoretically, I have sought to question many premises in conventional economics. Empirically, I use both existing large data sets and my own primary surveys. The latter enable me to address questions that have not been asked before, and sometimes arrive at unexpected answers. I will expand on each theme in turn, and then touch upon my engagement with policymaking and my current and planned research.

\section{Agriculture, technology, and food security}

I began working on agricultural modernisation and technological change in the 1970s, initially for my doctoral thesis on India, and later broadening it to other parts of Asia as well as Africa. In the 1970s, the Green Revolution in agriculture was at its height, based on a package of practices and inputs: high yielding varieties of rice and wheat, chemical fertilisers, and assured irrigation. To this was added mechanisation, especially tractors, in line with the American model of farming which served as a touchstone then. But was this choice of technology appropriate 
for a labour surplus country such as India? The prevailing view was that mechanisation would improve productive efficiency on Indian farms. I found that by empirically disaggregating the effects of mechanisation by techniques, operations, and farm size, I arrived at quite different results from those of aggregative studies. In particular, tractors, in themselves, added little to output while reducing labour demand. The thesis, published as a book, Mechanization in Indian Agriculture (Agarwal 1983), was appreciated for its methodological innovativeness and empirical results, and influenced the debate on farm mechanisation in India.

Subsequently I worked on the gender impact of High Yield Variety (HYV) seeds and mechanisation, comparing Asian and African countries and states within India. This work again challenged prevailing assumptions, but this time those of gender scholars who argued that mechanisation was bound to displace female labour. My results showed the opposite, since the operations in which most female labour was employed were not the ones being mechanised, again illustrating the importance of disaggregated analysis and careful empirical testing.

The Green Revolution brought food self-sufficiency to many developing countries in the 1980s, but today we are facing the consequences of falling groundwater tables and degraded soils, under the shadow of climate change. Common to both periods - the 1980s and today-however, is the limited visibility of women farmers in analysis, data and policies. This is despite a growing feminisation of agriculture globally, as more men than women first move to nonfarm jobs. In Asia and Africa, for instance, in 2012, 43\% and 47\% respectively of agricultural workers are women and their proportions have been growing. As I argue in several papers, our food security and farm output will thus depend increasingly on women farmers. Yet they have limited access to land, productive inputs, irrigation, information on new technologies, credit facilities, and markets. This reduces their productivity.

In contrast, my ongoing research in Asia, and the work of other scholars in Africa, shows that if women farmers had the same access to inputs as men, they could do as well, or even better. According to FAO's State of Food and Agriculture Report 2011, productivity on women's farms could rise by $20-30 \%$ as a result, and agricultural output in developing countries could be $2.5-4 \%$ higher. This potential remains untapped.

Women are also undercounted as workers. Their productive work for the household-fieldwork, cattlecare, fetching fodder and firewood, etc.-remains invisible, unpaid, and largely excluded from statistics. There is a vibrant debate today on why Indian women's labour force participation is so low. A paper I wrote in 1984 shows how biases in defining work and underreporting by male enumerators and respondents, not just in India but in many countries, can lead us to count women workers as non-working housewives. In fact, if we take a narrow definition based only on women's paid work, rural women's work participation in India today is only $17.5 \%$, but as recent research shows, if we take a wider definition and add homebased production, self-employment, and declared unemployment, we get a rate of 64.8\% (Dubey et al. 2017).

Many people also assume that women are less efficient than men. As a doctoral student, I found that agricultural economists were counting women's labour as equal 
to half of male labour simply because their wages were half of men's. In other words, labour market discrimination was being translated into academic bias. To challenge this, I needed evidence. Then I came across an experiment done by an engineer at the Punjab Agricultural University in North India. He had tested potatodigging equipment on women and men and found that women took one-third or half the time men took for the same job. In fact, women were more efficient by every measure. This helped me justify counting male and female labour at least as equal. It was the most debated point in my viva voce!

A related theme in my work was the gender impact of technology and women's access to it. I examined the impact of a range of technologies-from HYV crops to mechanised equipment and cooking stoves. Consider the case of stoves. When I was interviewing farmers in the Punjab, India's most prosperous state, I was struck by the fact that men were using tractors but their wives were still cooking with firewood and cropwaste on smoky stoves. Even today, many rural women cook on old stoves with firewood or other unprocessed biofuels. In fact, firewood remains the single most important cooking fuel in rural South Asia and Sub-Saharan Africa: $65 \%$ of rural households in India and $90 \%$ in Nepal use mainly firewood for cooking. This leads to indoor air pollution from cooking smoke, causing serious health problems. In developing countries, women's risk of mortality is found to be $50 \%$ higher than men's from smoke-related infections, and women account for $60 \%$ of the 1.6 million deaths per year just from this cause (Modi et al. 2005).

Many solutions have been offered for reducing kitchen smoke-from improved stoves to clean energy such as biogas. But the dissemination of these innovations to users remains a challenge. In the 1980s, the prevailing view, espoused by sociologists such as Everett Rodgers, was that people fail to adopt new technology due to ignorance of its benefits. In contrast, my research showed that technology adoption was restricted mainly by financial and social constraints faced by users, especially women. These and related ideas on the need to adapt technology to user needs, and the importance of bottom-up diffusion of innovations, are discussed in my 1986 book Cold Hearths and Barren Slopes: The Woodfuel Crises in the Third World (Agarwal 1986). In fact, women rarely have a say in the design of most equipment they use, especially agricultural equipment, and few own such equipment themselves. In Gambia, for instance, less than $1 \%$ of women farmers were found to own a seeder relative to $27 \%$ of male farmers. In Kenya, the value of farm equipment owned by women farmers was found to be $18 \%$ of that owned by male farmers (FAO 2011).

What underlies such gender inequalities? A key factor is women's unequal bargaining power within families and communities, the subject of my 1997 paper 'Bargaining and gender relations: within and beyond the household' (Agarwal 1997). In the late 1980s and 1990s a range of critiques emerged of the unitary household models I had mentioned earlier, and bargaining models of the household were presented as alternatives. Bargaining models depict intra-household relations more realistically as relations of both cooperation and conflict, driven by both selfinterest and altruism, with outcomes depending on a member's relative bargaining power. 
The key question this raised was: what affects a person's bargaining power? Most economists emphasised incomes. But, as I argue in my bargaining paper, bargaining power can also depend on other factors, some of which can be quantified, such as employment, ownership of private property, and access to public resources, while others are qualitative, such as social norms and perceptions. Women tend to be disadvantaged on most of these counts, and so have lower bargaining power than men within families, leading to further unequal outcomes.

In fact, the paper conceptualises bargaining as interactively occurring in four arenas: the family, the community, the market and the State. Interventions in one arena can affect bargaining power in other arenas. For instance, if the government transfers land or cash to women rather than men, it enhances women's bargaining power at home. Similarly, a husband who shares childcare can increase women's bargaining power in the labour market. But cutting across all the arenas is ownership of immovable property such as land or a house.

\section{Property and land rights}

This brings me to the second major focus of my research, namely gender inequalities in access to immovable property. In my 1994 book, A Field of One's own: Gender and Land Rights in South Asia (Agarwal 1994), and subsequent papers, I trace why it is so important for women to have independent rights in property, especially land. There are many reasons, such as: (a) for women's economic well-being and social status; (b) for productive efficiency on family farms; (c) for children's well-being: for instance, child survival, education and health are found to be significantly higher when the mother has assets than if the father alone has assets; and (d) for reducing women's risk of domestic violence.

This last point may surprise many, since most studies explain domestic violence in terms of culture, male alcohol abuse, or women's lack of employment. But based on a survey of 500 randomly selected households in Kerala (India), a colleague and I found that women's lack of property ownership mattered the most: $49 \%$ of propertyless women faced spousal violence, compared with only $7 \%$ of women owning a house and land. Owning immovable property significantly reduced women's risk of violence even after controlling for other factors. Notably, employment did not provide this protection, except formal sector employment which few Indian women have. In fact women who were better employed than their husbands were found more likely to face spousal violence (Agarwal and Panda 2007). Well-being outcomes can thus depend not just on a person's absolute capabilities (which Nobel Laureate Amartya Sen emphasizes), but also on their relative capabilities, an aspect which has received rather little attention.

However, studying women's rights in property and land was not easy. In South Asia most arable land is privately owned and few want to sell it, so inheritance is the main way of acquiring it. This means you first have to understand the inheritance laws. When I began my research on gender and property in the mid-1980s, there was very little written on the subject, even in terms of law. And I was researching not just India but five countries in South Asia. 
I found that inheritance laws differed not only by religion but also by region and type of property. The inheritance rights of, say, Hindu women were different in North India, South India, Nepal and Sri Lanka. Inheritance of land diverged even more. Hence whether or not a Hindu woman in India could inherit land depended on the state's land reform law. And in six states of North India, these laws replicated twelfth century legal treatises under which women could inherit land only in the absence of four generations of male heirs! But in Kerala (South India), among matrilineal Nayars, all property passed to and through women. To understand these diverse laws, I spent many months in Delhi's Law libraries, with dusty files and scores of mosquitoes, even surviving Falciparum malaria! Similarly I studied the laws of Sri Lanka, Bangladesh, Pakistan and Nepal, laboriously breaking new ground.

The labour was worth it. I gained enough understanding not only to write several papers but also to intervene effectively with civil society partners for amending India's Hindu inheritance law in 2005, to make it gender equal. And it brought me an invitation to teach law at the New York University School of Law in 2008.

Knowing the laws, however, is not enough. What about the gap between law and practice? Here I turned to anthropology. Reading hundreds of ethnographies, especially unpublished doctoral theses, gave me new insights. Luckily I was based at Harvard then and could access the material. Widener Library promised to acquire everything I needed from anywhere in the world on one condition: I could only order four theses a week! Very few of these anthropological writings dealt with women's property rights per se. But they provided details of kinship and marriage patterns which impinge on those rights. For example, fathers are much more willing to give daughters landed property in regions which allow marriages within villages and with close-kin, as in South India and Sri Lanka, than say in Northwest India where physically distant marriages with non-relatives are mandatory. Marriages to close-kin and in the village help keep land under the control of the extended family.

As an economist, however, I also wanted data to assess what percentage of women owned land. Here I hit a blank. Censuses and large surveys in most countries do not provide statistics on property ownership by gender. We thus have to depend on small surveys to provide pointers. In India, these show that less than 10-15\% women own land in the northwestern states and about 19-20\% do so in the southern states. Such inequalities are found across countries. In Kenya only 5\% of all registered landowners are women. In Ghana only $10 \%$ of women own land. In Latin America again there are notable gender inequalities in landownership among farm owners, varying by country.

In the late 1980s, when I was working on my book, A Field of One's Own, almost no one was focusing on women's rights in land and property. Today I am pleased to note that it has become a global issue, and a key part of Goal 5 on Gender Equality in the United Nation's Sustainable Development Goals. 


\section{Environment change and collective action}

My third major area of research is environment change and collective action. Sustainable development and environmental governance represent this century's biggest challenges. I examine the effects through a gender lens, focusing especially on forest governance.

In the early 1990s, given State failure in protecting forests, 50 countries launched community forestry programmes. India and Nepal were among the first. In 1998-1999 I travelled across both countries for six months, to see the results. The good news was that forests were improving in most states and regions. The bad news was that women were largely excluded from active participation in governance, a phenomenon I termed as 'participatory exclusions'.

In 2001, however, I decided to shift focus from women's history of absence to the impact of their presence. Would including women in forest governance really make a difference? If so, what percentage of women could be effective? Many cited onethird as the magic figure, but without testing it. So I conducted a primary survey in India and Nepal to answer these questions. I found that the presence of 25-33\% women indeed constituted a critical mass. With this percentage, women tended to attend meetings and take up leadership positions. Most importantly, their involvement significantly improved forest conservation. In Nepal, for instance, the likelihood of forest improvement was found to be $51 \%$ higher among all-women groups relative to male-dominated groups. These results are reported in my book, Gender and Green Governance (Agarwal 2010), and several journal articles.

Together, through this body of work, I have sought to cover the most important resources and institutions around private and public property that bear on gender inequality, while also affecting outcomes in the wider economy and society.

\section{Some running threads}

Notwithstanding the thematic diversity of my research, there are some common threads. First, although I am deeply committed to the idea of gender equality, in my research I choose to begin with an agnostic approach. I seek to question popular assumptions even within existing gender analysis, and test the assumptions with evidence and (data permitting) econometrically. This is essential, I believe, since research on social inequality, such as gender or race, can easily get coloured by ideology. And as scientists we must insist on evidence and report the results, even if they go contrary to our expected or preferred outcomes.

Second, I find that cross-regional and cross-country comparisons provide greater insights than is usually possible by focusing on one region or country. For instance, when probing the factors that affect women's property rights in South Asia, I found that the link between women's traditional land rights and their post-marital residence was only partly revealed in India but was confirmed when I studied Sri Lanka. The comparison also revealed the strength of cultural commonalities over religious differences. The pattern of women's land rights among Hindus in 
Northwest India, for example, was closer to that of Muslims in that region than to Hindus in Sri Lanka or South India. This observation helped counter the view that religion (rather than culture) was the main factor explaining gender differences in property ownership across communities and regions.

Third, crossing disciplinary boundaries has become increasingly necessary in social science. To understand inequality in property, for instance, we need to know the relevant aspects of law, economics, and anthropology. To understand agricultural systems, we need knowledge of agronomy and ecology. To understand natural resource governance, insights from political science and ecology are essential. Hence, although trained as an economist, I have drawn fruitfully from several disciplines.

Fourth, I use a mix of quantitative and qualitative methods, since much insight can be gained through qualitative evidence that remains hidden or is missed in statistical analysis, just as qualitative evidence alone, unsupported by quantification, limits the scope for generalisation.

Fifth, wherever possible, I try to tease out the policy implications of my research and suggest ways forward. Especially in relation to inequality, we not only need to understand the world but also find pathways to change it.

\section{Policy participation}

I have engaged with policy in three major ways. First is by direct participation in policymaking, such as by providing inputs for India's Plan documents, earlier formulated by the Planning Commission and now by the Niti Aayog.

Second, I support civil society groups who are working with women farmers and on women's land rights, by holding workshops at their request and writing up some of my research in a form that they can use. An example is my 2002 booklet: Are We Not Peasants Too? Translated into several Indian languages it was used to train village women. One NGO sent me the following feedback:

The village women consider the volume their prized possession. They carry it around even though they cannot read it, as they have memorized which page they may ask to be opened in a court room or during a village council meeting, to get across the fact that women do have land rights.

Third, in 2005 (as I had mentioned), my knowledge of India's inheritance laws came in handy for leading a civil society campaign to amend the Hindu Succession Act of 1956, to make it gender equal. The nine-month campaign included obtaining signatures from organisations and individuals across India on a petition seeking amendments in the law; sharing with all members of Parliament copies of the petition as well as information on the nature of the amendments we were seeking and why; depositions by myself and others before the Parliamentary Standing Committee on Law and Justice; and meeting with significant parliamentarians, including the then Prime Minister. In August 2005 the law was successfully amended to give Hindu women the same rights as men to inherit agricultural land 
and ancestral property. Since Hindus constitute $80 \%$ of India's population, this legally benefited some 500 million women and girls.

\section{Current and future work}

Let me end by briefly sharing the direction of my current and planned research. I am currently researching a little studied institutional innovation-group farming-in Asia and Europe. There is a global debate today on what kinds of farm enterprises could ensure food security and sustainable livelihoods. But the debate has focused mainly on small family farms versus large commercial farms, with little attention to a third model, namely group farming. This model would involve small farmers voluntarily pooling their land, labour and capital (without forfeiting private property rights), and sharing costs, risks and profits. Could this model of cooperation enable the vast numbers of small farmers (an increasing percentage of whom are women), to overcome their input constraints, enjoy economies of scale, and enhance their bargaining power vis-a-vis markets and the State. Can such a model outperform individual family farms? Under what 'design principles' might this model succeed and endure?

These seemingly simple questions pose notable challenges for collective action theory. Most existing work on collective action and resources revolves around governing common pool resources. Group farming involves cooperation around private property resources. I hope to make a theoretical contribution in this regard. Empirically I have thus far studied examples from India, France and Romania. Through the generous funds provided by the Balzan Prize, I plan to extend this work to other countries (including other parts of Europe), and also to build a theory of cooperation that identifies the principles for replicating the examples elsewhere. In addition, I plan to return to the issue of gender and inequality in property, using new data sources which are becoming available now.

To conclude, gender inequality remains one of the deepest forms of persisting inequalities today, especially as it intersects with other forms of inequality such as class, caste, and race. And it adversely affects not only a country's economy but also its social and political institutions. As scientists and practitioners, we need to continue exploring its many dimensions and seek pathways for its elimination. I hope that in time, with shifts in economic policies, laws, and social attitudes, all forms of gender inequality, including those highlighted by the Indian women farmers I cited at the start of my talk, will be consigned to history!

\section{References}

Agarwal, B. (1983). Mechanisation in Indian agriculture. Delhi: Allied Books.

Agarwal, B. (1986). Cold hearths and barren slopes: The woodfuel crises in the third world. London: Zed Books.

Agarwal, B. (1994). A field of one's own: Gender and land rights in South Asia. Cambridge: Cambridge University Press. 
Agarwal, B. (1997). Bargaining and gender relations: Within and beyond the household. Feminist Economics, 3(1), 1-51.

Agarwal, B. (2010). Gender and green governance. Oxford: Oxford University Press.

Agarwal, B. (2016). Gender Challenges. A three volume compendium. Delhi and Oxford: Oxford University Press.

Agarwal, B., \& Panda, P. (2007). Toward freedom from domestic violence: The neglected obvious. Journal of Human Development, 8(3), 359-388.

Dubey, A., Olsen, W., \& Sen, K. (2017). The decline in the labour force participation of rural women in India: Taking a long-run view. Indian Journal of Labour Economics. https://doi.org/10.1007/ s41027-017-0085-0.

FAO. (2011). The state of food and agriculture. Rome: Food and Agricultural Organisation.

Modi, V., McDade, S., Lallement, D., \& Saghir, J. (2005). Energy services for the Millennium Development Goals. Washington, DC: UNDP, World Bank, ESMAP.

Sen, A. (2009). The idea of justice. London: Penguin Books. 